Article

\title{
Characterization of Secondary Metabolites from Purple Ipomoea batatas Leaves and Their Effects on Glucose Uptake
}

\author{
Chia-Lin Lee ${ }^{1,2}$, Shou-Lun Lee ${ }^{3}$, Chao-Jung Chen ${ }^{4,5}$, Hsin-Chun Chen ${ }^{1}$, Ming-Ching Kao ${ }^{3,6}$, \\ Chuan-Hao Liu ${ }^{2}$, Jau-Yang Chen ${ }^{2}$, Yen-Ting Lai ${ }^{3}$ and Yang-Chang $\mathrm{Wu}^{2,7,8, *}$ \\ 1 Department of Cosmeceutics, China Medical University, Taichung 40402, Taiwan; \\ chlilee@mail.cmu.edu.tw (C.-L.L.); c0706@mail.cmu.edu.tw (H.-C.C.) \\ 2 Chinese Medicine Research and Development Center, China Medical University Hospital, Taichung 40447, \\ Taiwan; bc00025@yahoo.com.tw (C.-H.L.); day_7749@hotmail.com (J.-Y.C.) \\ 3 Department of Biological Science and Technology, China Medical University, Taichung 40402, Taiwan; \\ sllee@mail.cmu.edu.tw (S.-L.L.); mckao@mail.cmu.edu.tw (M.-C.K.); wawagay@hotmail.com (Y.-T.L.) \\ 4 Graduate Institute of Integrated Medicine, China Medical University, Taichung 40402, Taiwan; \\ cjchen@mail.cmu.edu.tw \\ 5 Proteomics Core Laboratory, Department of Medical Research, China Medical University Hospital, \\ Taichung 40447, Taiwan \\ 6 Department of Biochemistry, National Defense Medical Center, Taipei 11466, Taiwan \\ 7 School of Pharmacy, China Medical University, Taichung 40402, Taiwan \\ 8 Graduate Institute of Natural Products, Kaohsiung Medical University, Kaohsiung 80708, Taiwan \\ * Correspondence: yachwu@mail.cmu.edu.tw; Tel.: +886-4-2205-7153; Fax: +886-4-2206-0248
}

Academic Editor: Derek J. McPhee

Received: 5 May 2016; Accepted: 3 June 2016; Published: 8 June 2016

\begin{abstract}
Ipomoea batatas has long been used in folk medicine for the treatment of hyperglycemia or as a food additive for the prevention of type 2 diabetes. However, neither the plant extract nor its active components have been evaluated systematically. In this work four crude extracts, including n-hexane- (IBH), $95 \% \mathrm{MeOH}$ - (IBM), $n$-BuOH- (IBB), and $\mathrm{H}_{2} \mathrm{O}$-soluble (IBW) fractions, were prepared by fractionation of a methanolic extract of purple I. batatas leaves. Twenty-four pure compounds 1-24 were then isolated by various chromatographic techniques and their structures identified from NMR and MS data. Glucose uptake assays in differentiated 3T3-L1 adipocytes and rat primary hepatocytes, as well as western blot analysis, were carried out to evaluate the antidiabetic activity of this species. The IBH crude fraction, with methyl decanoate (22) as a major and active compound, showed the greatest effect on glucose uptake, most likely via activation of Glut4 and regulation of the PI3K/AKT pathway. Quercetin 3-O- $\beta$-D-sophoroside (1), quercetin (3), benzyl $\beta$-d-glucoside (10), 4-hydroxy-3-methoxybenzaldehyde (12), and methyl decanoate (22) could be important components contributing to the antidiabetic effects. We conclude that purple $I$. batatas leaves have potential as an antidiabetic plant source and the active constituents 1, 3, 10, 12, and 22 are promising lead candidates for future investigation.
\end{abstract}

Keywords: Ipomoea batatas; purple sweet potato leaves; glucose uptake effect

\section{Introduction}

Ipomoea batatas (L.) (Convolvulaceae), commonly known as sweet potato, is a well-known valuable medicinal food. While the roots and leaves of I. batatas play important roles as an energy source for humans and animals, they also have been used in traditional medicine for the treatment of various diseases [1]. Numerous pharmacological properties, including antidiabetic (caffeic acid 
derivatives, anthocyanosides, flavonoids, arabinogalactan-protein) [1-3], anti-oxidant (caffeic acid derivatives, anthocyanosides, coumarins) $[1,4,5]$, anticancer (caffeic acid derivatives, anthocyanosides, coumarins) [1], antimicrobial (caffeic acid derivatives, triterpenes) [1], anticoagulant (coumarins) [1], and anti-inflammatory (resin glycosides) [6] activities, have been reported for this species. The green I. batatas leaves have long been used in folk medicine for the treatment of hyperglycemia or as a food additive for the prevention of type 2 diabetes [7-9], while the purple I. batatas leaves contain large quantities of rough fibers and in Taiwan they are usually discarded or fed to animals. A systematic investigation of the active antidiabetic compounds isolated from the latter variety has not been reported. Therefore, as part of our studies to identify promising antidiabetic drugs from natural products, the active components of purple sweet potato leaves were elucidated herein.

\section{Results and Discussion}

\subsection{Glucose Uptake Efficacy of Four Crude Fractions Prepared from Purple I. batatas Leaves}

A $\mathrm{MeOH}$ extract of the aerial parts of purple I. batatas was separated into $n$-hexane- (IBH), $95 \% \mathrm{MeOH}-(\mathrm{IBM}), n-\mathrm{BuOH}-(\mathrm{IBB})$, and $\mathrm{H}_{2} \mathrm{O}$-soluble (IBW) fractions by liquid-liquid partition chromatography (see Section 3.3. Extraction and Isolation). 3T3-L1 adipocyte and primary rat hepatocyte models were used to evaluate the glucose uptake efficacy of the above four fractions.

In MTT and trypan blue assays, IBM was cytotoxic to 3T3-L1 preadipocytes (Figure 1A,B). In contrast, IBH, IBB, and IBW exhibited no significant cytotoxicity toward differentiated 3T3-L1 preadipocytes in the MTT assay (Figure 1C), while IBB was cytotoxic to primary rat hepatocytes (Figure 1D). Therefore, only IBH and IBW were tested for glucose uptake in 3T3-L1 adipocytes and rat hepatocytes. IBH showed a significant effect in both models (Figure 2A,B), while IBW affected glucose uptake activity only in the latter model.

A.

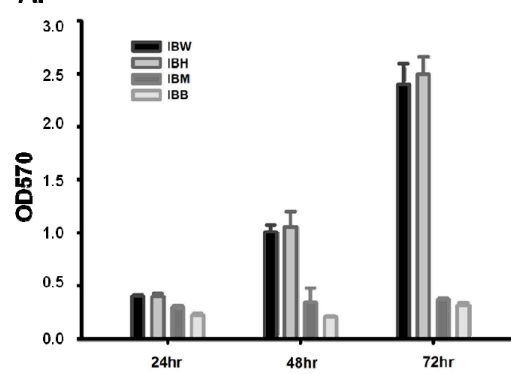

c.

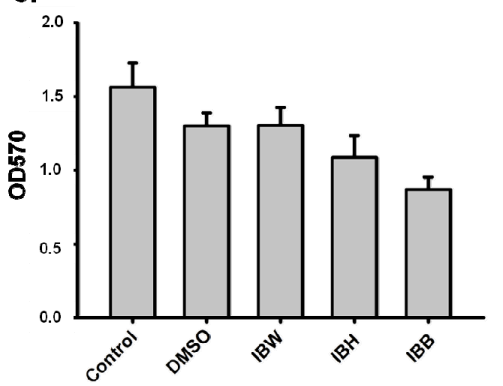

B.

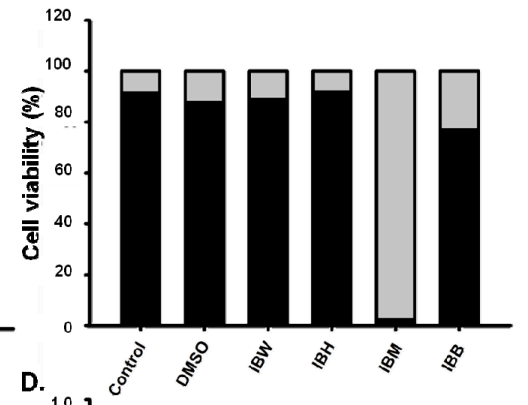

D.

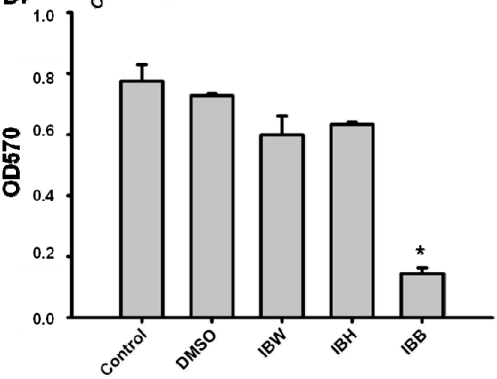

Figure 1. Cytotoxicity testing with IBH, IBM, IBB, and IBW crude fractions. (A) MTT assay for 3T3-L1 preadipocytes $\left(1 \times 10^{4}\right.$ cells $\left./ \mathrm{cm}^{2}\right)$ treated with $0.1 \mathrm{mg} / \mathrm{mL}$ of IBH, IBM, IBB, and IBW; (B) Trypan blue assay for 3T3-L1 preadipocytes treated with extract $(0.1 \mathrm{mg} / \mathrm{mL})$ for $72 \mathrm{~h}$. Survival and mortality rates of cells are marked in black and gray, respectively; (C) MTT assay of 3T3-L1 differentiated adipocytes $\left(1 \times 10^{5}\right.$ cells/well, 12 wells) treated with $0.1 \mathrm{mg} / \mathrm{mL}$ of IBH, IBB, and IBW in $10 \%$ FBS medium for $72 \mathrm{~h}$; (D) MTT assay of primary rat hepatocytes $\left(1 \times 10^{5}\right.$ cells/well, 12 wells collagen coating $)$ treated with $0.1 \mathrm{mg} / \mathrm{mL}$ of IBH, IBB, and IBW for $24 \mathrm{~h}$. ANOVA statistical analysis, ${ }^{*} p<0.05$. 
A. 3T3-L1 adipocytes

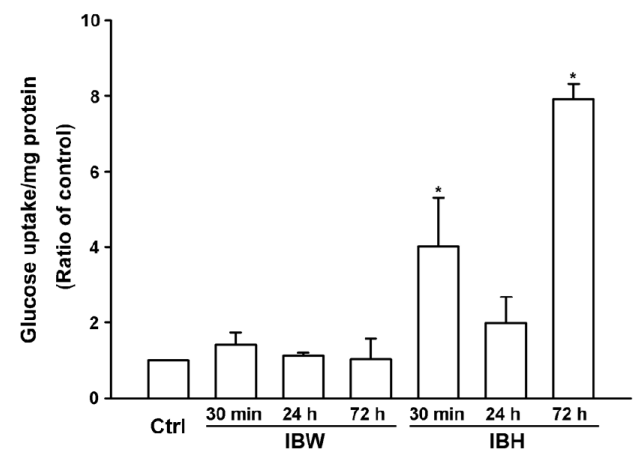

B. Rat primary hepatocytes

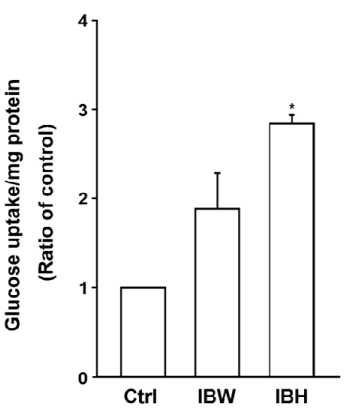

Figure 2. Glucose uptake test for IBH and IBW crude fractions. (A) Glucose uptake test in 3T3-L1 adipocytes: Differentiated 3T3-L1 adipocytes were treated with $0.1 \mathrm{mg} / \mathrm{mL}$ of IBW and IBH for $30 \mathrm{~min}$, $24 \mathrm{~h}$, and $72 \mathrm{~h}$; (B) Glucose uptake test in rat primary hepatocytes: Hepatocytes $\left(1 \times 10^{5}\right.$ cells/well, 12 wells collagen coating) were treated with $0.1 \mathrm{mg} / \mathrm{mL}$ of IBW and IBH for $24 \mathrm{~h}$. The amount of 2-NBDG (2-[N-(7-nitrobenz-2-oxa-1,3-diazol-4-yl)amino]-2-deoxyglucose) taken up by cells was measured by the fluorescence at excitation and emission wavelengths (485 and $535 \mathrm{~nm}$, respectively). DMSO $(0.2 \%)$ was used as the control group for IBH. Statistical analysis was performed with ANOVA, * $p<0.05$.

As shown in Figure 3, IBH increased the phosphorylation of PI3K, AKT, and Glut4 in 3T3-L1 adipocytes; however, IBW increased only p-PI3K. These data suggest that IBH might activate Glut4 by regulating the PI3K/AKT pathway.

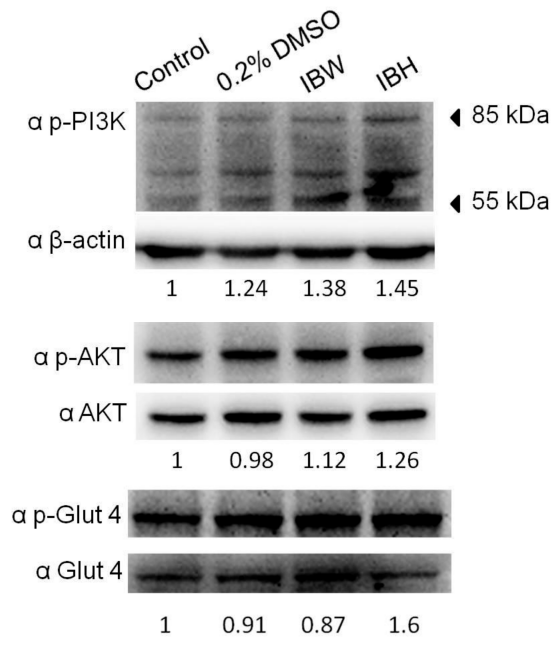

Figure 3. The effects of extracts on PI3K/AKT/Glut4 expression in mature 3T3-L1 adipocytes. Cells were treated with $0.1 \mathrm{mg} / \mathrm{mL}$ of IBW and IBH crude extracts for $24 \mathrm{~h}$, and then analyzed for PI3K, AKT, Glut4, and $\beta$-actin by western blot analysis.

\subsection{Chemical Composition of the $n$-Hexane-Soluble Fraction (IBH)}

The chemical composition of the $n$-hexane fraction (IBH) was analyzed by GC/MS as shown in Table 1 (see Supplementary Materials for details). The three major components in this fraction

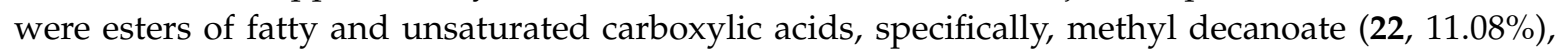
methyl cinnamate $(23,14.12 \%)$, and methyl laurate $(24,14.24 \%)$. Among the 47 minor compounds also identified, terpenoids constituted $12.70 \%$, including eleven sesquiterpenes $(6.67 \%)$ and two monoterpenes $(5.92 \%)$. Fourteen aromatic compounds $(20.08 \%)$, two acids $(1.16 \%)$, two additional 
esters $(0.70 \%)$, three aldehydes $(0.95 \%)$, two ketones $(2.70 \%)$, two alcohols $(1.27 \%)$, six alkanes $(5.45 \%)$, and three alkenes $(2.45 \%)$ were also determined (Table 1$)$. However, other compounds $(13.21 \%)$ in the IBH fraction remained unknown. An earlier report studied the volatiles from purple I. batatas leaves and identified major (germacrene $\mathrm{D}$, germacrene $\mathrm{B}$, caryophyllene, and $n$-hexadecanoic acid) and minor (benzaldehyde, nonanal, $\beta$-elemene, isocaryophyllene, (-)- $\beta$-caryophyllene epoxide etc.) constituents of this plant [10]. In the present study, we also found germacrene $\mathrm{D}(0.16 \%)$, benzaldehyde $(0.22 \%)$, nonanal $(0.50 \%), \beta$-elemene $(0.72 \%)$, isocaryophyllene $(0.13 \%)$, and $(-)$ - $\beta$-caryophyllene epoxide $(2.69 \%)$ in I. batatas. However, the major components found in the two studies were not the same [10]. Different environment, plant cultivation, collection period, extraction methodology, and analytical techniques could account for the differences.

Table 1. Chemical composition of $n$-hexane-soluble fraction from purple I. batatas leaves.

\begin{tabular}{|c|c|c|c|c|}
\hline$R_{\mathrm{t}}(\min )^{\mathrm{a}}$ & $\mathbf{R I}^{\mathbf{b}}$ & Compound & Peak Area (\%) & Classification \\
\hline 12.04 & 860 & Pentanoic acid & 0.37 & acid \\
\hline 14.21 & 927 & Benzaldehyde & 0.22 & aldehyde \\
\hline 15.11 & 955 & Hexanoic acid & 0.79 & acid \\
\hline 15.25 & 959 & 6-Methyl-5-hepten-2-one & 0.68 & ketone \\
\hline 15.89 & 978 & 1,2,4-Trimethylbenzene & 0.61 & aromatic compound \\
\hline 16.44 & 994 & Decane & 0.37 & alkane \\
\hline 16.77 & 1004 & 1,2,3-Trimethylbenzene & 1.23 & aromatic compound \\
\hline 16.86 & 1007 & 2-Ethylhexanol & 0.96 & alcohol \\
\hline 17.64 & 1033 & $m$-Diethylbenzene & 0.29 & aromatic compound \\
\hline 17.72 & 1036 & m-Propyltoluene & 0.49 & aromatic compound \\
\hline 17.93 & 1043 & $o$-Cymene & 1.30 & aromatic compound \\
\hline 18.21 & 1052 & $o$-Propyltoluene & 0.31 & aromatic compound \\
\hline 18.53 & 1062 & 2-Ethyl-1,4-dimethylbenzene & 1.06 & aromatic compound \\
\hline 18.59 & 1063 & 2-Ethyl-1,3-dimethylbenzene & 2.25 & aromatic compound \\
\hline 18.70 & 1067 & 3-Methyldecane & 0.20 & alkane \\
\hline 18.87 & 1072 & 6-Methyl-3,5-heptadien-2-one & 2.02 & ketone \\
\hline 19.06 & 1078 & Nonanal & 0.50 & aldehyde \\
\hline 19.41 & 1088 & 4-Ethyl-1,2-dimethylbenzene & 0.83 & aromatic compound \\
\hline 19.59 & 1094 & Undecane & 2.59 & alkane \\
\hline 19.79 & 1100 & 1,2,3,4-Tetramethylbenzene & 3.63 & aromatic compound \\
\hline 19.90 & 1104 & $1,2,4,5$-Tetramethylbenzene & 4.38 & aromatic compound \\
\hline 20.39 & 1121 & $(+)$-2-Bornanone & 1.82 & monoterpene \\
\hline 20.54 & 1127 & 1,3-Diethyl-5-methylbenzene & 0.58 & aromatic compound \\
\hline 20.73 & 1133 & 1-Menthone & 4.10 & monoterpene \\
\hline 20.86 & 1138 & 1-Ethyl-3,5-dimethylbenzene & 1.52 & aromatic compound \\
\hline 21.46 & 1159 & Butoxyethoxyethanol & 0.31 & alcohol \\
\hline 21.62 & 1104 & Naphthalene & 1.60 & aromatic compound \\
\hline 22.15 & 1182 & Decanal & 0.23 & aldehyde \\
\hline 22.26 & 1186 & 1-Dodecene & 1.45 & alkene \\
\hline 22.59 & 1196 & Dodecane & 1.71 & alkane \\
\hline 25.20 & 1289 & Methyl 4-decenoate & 0.59 & ester \\
\hline 25.48 & 1297 & Tridecane & 0.15 & alkane \\
\hline 25.66 & 1303 & Methyl decanoate & 11.08 & ester \\
\hline 26.85 & 1356 & Methyl cinnamate & 14.12 & ester \\
\hline 27.46 & 1382 & Bicyclogermacrene & 0.54 & sesquiterpene \\
\hline 27.52 & 1384 & $\alpha$-Copaene & 0.94 & sesquiterpene \\
\hline 27.62 & 1388 & trans-2-Tetradecene & 0.23 & alkene \\
\hline 27.74 & 1393 & $\beta$-Elemene & 0.72 & sesquiterpene \\
\hline 27.85 & 1398 & Tetradecane & 0.43 & alkane \\
\hline 27.98 & 1404 & Methyl undecanoate & 0.11 & ester \\
\hline 28.06 & 1408 & (-)-Isoledene & 0.18 & sesquiterpene \\
\hline 28.46 & 1429 & Isocaryophyllene & 0.13 & sesquiterpene \\
\hline 28.61 & 1437 & $\beta$-Cubebene & 0.12 & sesquiterpene \\
\hline 29.25 & 1470 & Aromadendren & 0.38 & sesquiterpene \\
\hline
\end{tabular}


Table 1. Cont.

\begin{tabular}{ccccc}
\hline $\boldsymbol{R}_{\mathbf{t}} \mathbf{( m i n}^{\mathbf{a}}$ & $\mathbf{R I}^{\mathbf{b}}$ & Compound & Peak Area (\%) & Classification \\
\hline 29.42 & 1479 & Germacrene D & 0.16 & sesquiterpene \\
29.71 & 1493 & $\beta$-Selinene & 0.81 & sesquiterpene \\
29.96 & 1506 & Methyl laurate & 14.24 & ester \\
31.38 & 1578 & 1Z,5E-7-Dodecatriene & 0.77 & alkene \\
31.53 & 1586 & $(-)-\beta$-Caryophyllene epoxide & 2.69 & sesquiterpene \\
& & Total & 86.79 & \\
\hline
\end{tabular}

${ }^{\text {a }} R_{\mathrm{t}}$ : Retention time (min); ${ }^{\mathrm{b}} \mathrm{RI}$ : Retention index, using paraffin $\left(\mathrm{C}_{5}-\mathrm{C}_{25}\right)$ as reference.

\subsection{Chemical Composition of $95 \% \mathrm{MeOH}$ - and $n-B u O H$-soluble Fractions (IBM and IBB)}

Twenty-one components were isolated from the IBM (compounds 10-21) and IBB (compounds 1-9) extracts of purple $I$. batatas leaves (Figure 4 and Table S1). The polarities of compounds 1-21 in both crude fractions were higher than those in IBH. Three flavonoids, quercetin 3-O- $\beta$-D-sophoroside (1) [11], quercetin 3 $\beta$-O-glucoside (2) [12], and quercetin (3) [12], one caffeic acid derivative, 3,4-di-O-caffeoyl isoquinic acid (4) [13], three sesquiterpenes, ananosmoside $\mathrm{A}$ (5) [14], caryolane-1,9 $\beta$-diol (14) [15], and clovane-2 $\beta, 9 \alpha$-diol (15) [15], one iridoid glucoside, 8-O-acetyl-harpagide (6) [16], one monoterpenoid triol (7) [17,18], two phenylpropanoids, eugenyl O- $\beta$-D-glucopyranoside (8) [19] and eugenol (11) [20], one ligand, (+)-pinoresinol- $\beta$-d-glucoside (9) [21], three benzene derivatives, benzyl $\beta$-D-glucoside (10) [22], 4-hydroxy-3-methoxybenzaldehyde (12) [23], and methyl 4-hydroxy-3-methoxybenzoate (13) [24], one alkaloid, indole-3-aldehyde (16) [25], one coumarin, 6-methoxy-7-hydroxycoumarin (17) [26], one amide, trans- $N$-feruloyltyramine (18) [27], one isoprene derivative, 2-methyl-1,2,3,4-butanetetrol (19) [28], one diterpene, andrographolide (20) [29], and one steroid, sitosterol-3- $\beta$-D-glucose (21) [30] were identified from the NMR and MS spectroscopic data (see Supplementary Materials). Except for 3, 17, and 21, the remaining compounds were reported for the first time from this plant.

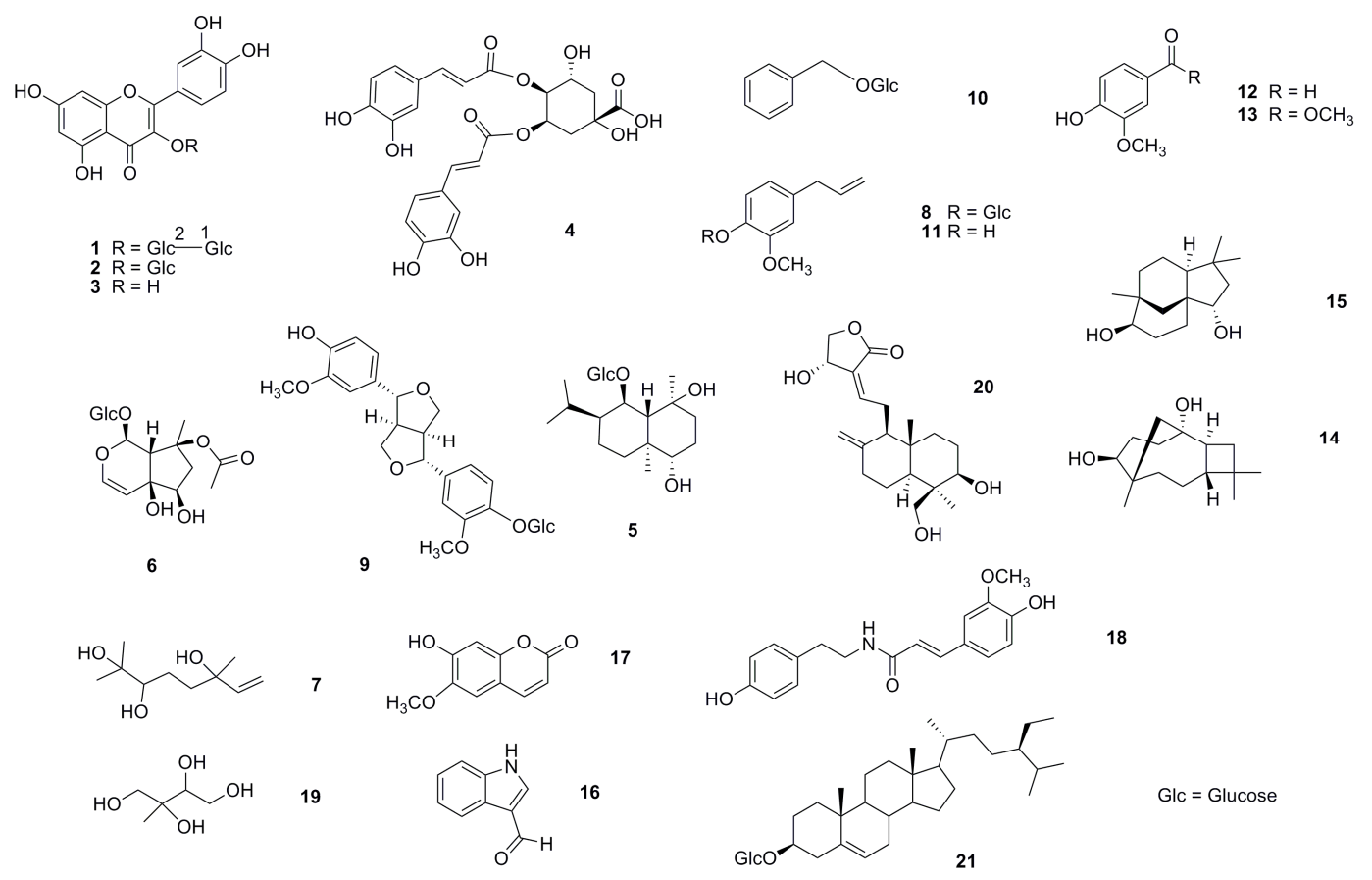

Figure 4. Structures of compounds 1-21 isolated from the IBM (compounds 10-21) and IBB (compounds 1-9) crude fractions. 


\subsection{Chemical Composition of the $\mathrm{H}_{2} \mathrm{O}$-Soluble Fraction (IBW)}

In the 1D and 2D NMR spectra (Figures S1-S6) of the IBW crude fraction, the major signals were similar to those of compound 19 (Figures S7 and S8), which was isolated from the IBM crude fraction. In the LC/MS analysis of IBW, peaks were found at $m / z 137.0838[\mathrm{M}+\mathrm{H}]^{+}$and $135.0634[\mathrm{M}-\mathrm{H}]^{-}$, which could possibly be assigned to compound 19, although two different retention times were also observed (Figure S11). However, 2-methyl-1,2,3,4-butanetetrol (19) has four stereoisomers, (2S,3R)or $(2 R, 3 S)-2-C$-methylerythritol and $(2 S, 3 S)$ - or $(2 R, 3 R)-2-C$-methylthreitol [28,31] (Figure S12). Thus, based on our data, the major constituent of IBW is 2-methyl-1,2,3,4-butanetetrol (19), occurring as a mixture of stereoisomers. Compound 19 is a photooxidative isoprene emitted by plants and has been reported as a major contributor to secondary organic aerosols in the atmosphere [31]. Besides, it could be speculated that saccharide components of the IBW crude fraction account for the remaining NMR chemical shifts between 3.0-6.5 and 60-110 ppm in the ${ }^{1} \mathrm{H}$ - and ${ }^{13} \mathrm{C}-\mathrm{NMR}$ spectra, respectively (Figures S1 and S2). Acid hydrolysis and HPLC analysis possibility indicated D-galactose (15.94 min), L-galactose (16.53 min), D-glucose (18.34 min), L-arabinose (20.31 min), and D-arabinose (22.01 min) units in IBW extract compared with sugar derivatives standards: D-galactose (16.01 min), L-galactose (16.57 min), D-glucose (18.36 min), L-arabinose (20.51 min), and D-arabinose (21.85 min) (see Section 3.6 and Figure S13).

\subsection{Glucose Uptake Effect of the Components from IBH, IBM, IBB, and IBW}

Adipocytes regulation of glucose uptake can decrease postprandial hyperglycemia. To determine the effect of the isolates from purple I. batatas leaves on glucose uptake and identify potential promising antidiabetic natural products leads, we evaluated selected isolated compounds in an insulin-stimulated glucose uptake assay using differentiated 3T3-L1 adipocytes and a fluorescent D-glucose analog (2-NBDG). Because the IBH fraction showed significant effects on glucose uptake (Figure 2), its three major components 22-24 (Table 1), purchased from commercial companies (see Section 3.1. General Procedures), were studied. Among these three compounds, only methyl decanoate (22) increased glucose uptake $(27.5 \%)$ relative to the control (Figure 5).

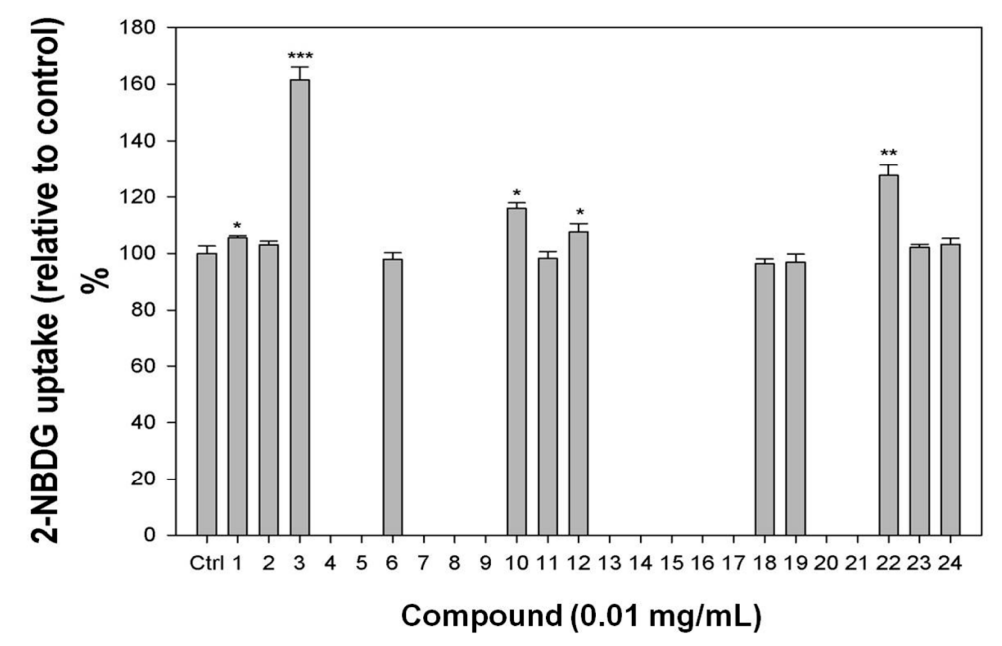

Figure 5. Glucose uptake test in differentiated 3T3-L1 adipocytes for pure compounds 1-24. Differentiated 3T3-L1 adipocytes were treated with compound for $30 \mathrm{~min}$, and then 2-NBDG uptake was measured. Compounds 4-5, 7-9, 13-17, and 20-21 were cytotoxic toward 3T3-L1 adipocytes and were not tested in this assay. ANOVA statistical analysis: ${ }^{*}, p<0.05 ;{ }^{* *}, p<0.01 ;{ }^{* * *}, p<0.005$.

With the exception of 4-5, 7-9, 13-17, and 20-21, which were cytotoxic toward 3T3-L1 adipocytes and contributed to the cytotoxic properties of IBM and IBB, all components (Figure 4) isolated from IBM and IBB crude fractions were also tested in the glucose uptake assay. As shown 
in Figure 5, quercetin 3-O- $\beta$-D-sophoroside (1), quercetin (3), benzyl $\beta$-D-glucoside (10), and 4-hydroxy-3-methoxybenzaldehyde (12) increased 2-NBDG uptake rates by $5.4 \%, 61.4 \%, 15.8 \%$, and $7.5 \%$, respectively relative to the control. Compound 19, which was found in IBM and also identified as the major component of IBW, did not affect the cells' glucose uptake rate.

In people with type II diabetes, insulin-induced stimulation of hepatic, muscle, and adipose tissue glucose uptake is impaired [32-35]. Among numerous structurally diverse natural products affecting glucose uptake [35-45], flavonoids are a predominant factor [36-40]. Among isolates 1-24, compounds 1-3 are flavonol derivatives and quercetin (3) was identified in our study as the most active single component of purple I. batatas leaves. In 2008, Fang reported that 3 could significantly improve insulin-stimulated glucose uptake in mature 3T3-L1 adipocytes by acting as a partial agonist of PPAR $\gamma$ [46]. Although flavonoid $\mathbf{1}$ is a sugar derivative of $\mathbf{3}$, it had a much lower effect than 3 on glucose uptake. Additionally, compound 2 (flavonol-3-glucoside) did not affect glucose uptake, even though 2 is structurally similar to cyanidin-3-glucoside [39]. In 2011, Nidhina et al. reported that vanillin (4-hydroxy-3-methoxybenzaldehyde, 12) could increase glucose uptake, as well as the expression levels of PPAR $\gamma$ and its target gene Glut4 in 3T3-L1 cells [47]. Our research study has first reported the glucose uptake activities of compounds $\mathbf{1 , 1 0}$, and $\mathbf{2 2}$. These compounds, as well as $\mathbf{3}$ and 12, merit further research as possible natural products leads in antidiabetic drug development.

\section{Materials and Methods}

\subsection{General Procedures}

1D and 2D NMR spectra were measured on a $500 \mathrm{MHz}$ Avance III (Bruker, Rheinstetten, Germany). Chemical shift $(\delta)$ values are reported in ppm (part per million) with pyridine- $d_{5}$ and methanol- $d_{4}$ as internal standard, and coupling constants $(J)$ are in Hz. Low-resolution ESIMS were measured on a Bruker Daltonics EsquireHCT ultra high capacity trap mass spectrometer. TLC was performed on Kieselgel $60 \mathrm{~F}_{254}\left(0.25 \mathrm{~mm}\right.$, Merck, Darmstadt, Germany) or RP-18 $\mathrm{F}_{254} \mathrm{~S}$ (0.25 mm, Merck), and spots were viewed under UV light at 254 and $356 \mathrm{~nm}$ and then stained by spraying with $10 \% \mathrm{H}_{2} \mathrm{SO}_{4}$ and heating on a hot plate. For column chromatography, silica gel (SILICYCLE 70-230 and 230-400 mesh), RP-18 (LiChroprep ${ }^{\circledR}$ 40-63 $\mu \mathrm{m}$, Merck), Sephadex ${ }^{\mathrm{TM}}$ LH-20 (GE Healthcare, Uppsala, Sweden) and Diaion ${ }^{\circledR}$ HP-20 (Supelco ${ }^{\mathrm{TM}}$, Bellefonte, PA, USA) were used. A Shimadzu LC-20AT pump, Shimadzu RID-10A refractive index detector/SPD-M20A diode array detector (Shimadzu Inc., Kyoto, Japan) with a SUPELCO ${ }^{\mathrm{TM}}$ Ascentis $^{\circledR}$ and Discovery HS ${ }^{\circledR}\left(250 \times 10 \mathrm{~mm}\right.$ i.d., $\left.5 \mu \mathrm{m}, \mathrm{C}_{18}\right)$ columns with $2 \mathrm{~mL} / \mathrm{min}$ flow rate were used for HPLC. Methyl laurate (Chem Service, West Chester, PA, USA), methyl cinnamate (Aldrich, St. Louis, MO, USA), and methyl decanoate (Chem Service, West Chester, PA, USA) were used for GC/MS analysis.

\subsection{Plant Material}

Aerial parts of purple I. batatas leaves $(5.0 \mathrm{~kg})$ were collected in Luzhu District, Taoyuan City, Taiwan $\left(121^{\circ} 17^{\prime} 7.28^{\prime \prime} \mathrm{E}, 25^{\circ} 4^{\prime} 42.03^{\prime \prime} \mathrm{N}\right)$, in July, 2013 by the author M.C. Kao. The plants were cultivated on Prof. Kao's private farmland with his permission to conduct a study on this species. The plant was authenticated by the National Plant Resources Center of Taiwan Agricultural Research Institute with the account number Pin 375. A voucher specimen (IB2013-2014) was deposited at CMRDC, China Medical University Hospital, Taiwan.

\subsection{Extraction and Isolation}

The aerial parts of $I$. batatas $(5.0 \mathrm{~kg})$ were extracted three times with $\mathrm{MeOH}(30.0 \mathrm{~L}$ each) at room temperature to obtain a crude extract. The $\mathrm{MeOH}$ extract $(350.0 \mathrm{~g})$ was partitioned between EtOAc and $\mathrm{H}_{2} \mathrm{O}(1: 1, v / v)$ to give an EtOAc-soluble fraction and an aqueous phase, which were further partitioned between $n$-hexane $/ 95 \% \mathrm{MeOH}$ and $n-\mathrm{BuOH} / \mathrm{H}_{2} \mathrm{O}(1: 1, v / v)$, respectively, to give $\mathrm{n}$-hexane- (IBH), $95 \%$ $\mathrm{MeOH}-$ (IBM), n- $\mathrm{BuOH}-$ (IBB), and $\mathrm{H}_{2} \mathrm{O}$-soluble (IBW) extracts. 
Fractionation of extract IBM (30.0 g) was carried out by silica gel chromatography (column diameter: $9 \mathrm{~cm}$, length: $20 \mathrm{~cm} ; \mathrm{CH}_{2} \mathrm{Cl}_{2} / \mathrm{MeOH}, 30: 1$ ), yielding six fractions (IBM1-IBM6). Fraction IBM1 (1.2 g) was subjected to open column chromatography on silica gel (column: $2.5 \times 28 \mathrm{~cm}$; $\mathrm{CH}_{2} \mathrm{Cl}_{2} / n$-hexane, 5:1) and gave eight subfractions (IBM1.1-IBM1.8). Subfraction IBM1.2 (58.7 mg) was partitioned by RP-18 chromatography (column: $2 \times 27 \mathrm{~cm} ; \mathrm{MeOH} / \mathrm{H}_{2} \mathrm{O}, 90: 10$ ) and purified by preparative TLC ( $n$-hexane/EtOAc, 5:1) to give $\mathbf{1 1}(3.1 \mathrm{mg})$. Subfraction IBM1.5 (93.5 $\mathrm{mg}$ ) was subjected to silica gel column chromatography (column: $2 \times 30 \mathrm{~cm}$; $n$-hexane/EtOAc, 5:1) to give pure 13 (11.1 mg). Subfraction IBM1.6 (67.0 mg) was partitioned by silica gel chromatography (column: $2 \times 30 \mathrm{~cm}$; $n$-hexane/EtOAc, 5:1) and purified by preparative TLC $\left(\mathrm{CH}_{2} \mathrm{Cl}_{2} / \mathrm{MeOH}, 5: 1\right)$ to give 12 $(3.8 \mathrm{mg})$. Fraction IBM2 $(8.3 \mathrm{~g})$ was divided into four subfractions by Sephadex LH-20 (column: $\left.5 \times 50 \mathrm{~cm} ; \mathrm{CH}_{2} \mathrm{Cl}_{2} / \mathrm{MeOH}, 1: 1\right)$ and subfraction IBM2.3 (1.2 g) was separated into seven subfractions by column chromatography on silica gel (column: $2.5 \times 28 \mathrm{~cm}$; $n$-hexane/EtOAc, 3:1). Subfraction IBM2.3.6 (82.5 mg) was subjected to RP-18 column chromatography (column: $2 \times 28 \mathrm{~cm} ; \mathrm{MeOH} / \mathrm{H}_{2} \mathrm{O}$, 3:2) and purified by preparative TLC $\left(\mathrm{CH}_{2} \mathrm{Cl}_{2} / \mathrm{MeOH}, 100: 1\right)$ to give $\mathbf{1 7}(4.0 \mathrm{mg})$. Subfraction IBM2.4 $(354.2 \mathrm{mg}$ ) was chromatographed on a silica gel column (column: $2.5 \times 28 \mathrm{~cm}$ ), using $n$-hexane/EtOAc (3:1) as eluent. Subfraction IBM2.4.5 (17.5 $\mathrm{mg}$ ) was partitioned by silica chromatography (column: $\left.1.5 \times 28 \mathrm{~cm} ; \mathrm{CH}_{2} \mathrm{Cl}_{2} / \mathrm{MeOH}, 50: 1\right)$ to give $16(2.1 \mathrm{mg})$. Sephadex LH-20 chromatography (column: $\left.5 \times 50 \mathrm{~cm} ; \mathrm{CH}_{2} \mathrm{Cl}_{2} / \mathrm{MeOH}, 1: 1\right)$ of Fraction IBM3 (9.0 g) gave compound $21(100.0 \mathrm{mg})$ as well as four impure subfractions. Subfraction IBM3.3 (3.1 g) was subjected to RP-18 (column: $2.5 \times 28 \mathrm{~cm}$; $\left.\mathrm{MeOH} / \mathrm{H}_{2} \mathrm{O}, 3: 1\right)$ chromatography to give IBM3.3.2 (1.3 g) and IBM3.3.4 (113.8 mg). Subfraction IBM3.3.2 was separated by RP-18 (column: $5 \times 28 \mathrm{~cm}$; $\mathrm{MeOH} / \mathrm{H}_{2} \mathrm{O}, 1: 1$ ) into seven subfractions (IBM3.3.2.1-IBM3.3.2.7). Subfraction IBM3.3.2.4 (160.9 mg) was chromatographed on silica gel (column: $2 \times 28 \mathrm{~cm} ; \mathrm{EtOAc} / \mathrm{MeOH}, 100: 1$ and $\left.\mathrm{CH}_{2} \mathrm{Cl}_{2} / \mathrm{MeOH}, 20: 1\right)$, and further purified by preparative TLC ( $n$-hexane/EtOAc, 1:1 and $n$-hexane/acetone, 1:1) to give 18 (3.4 mg). Subfraction IBM3.3.2.5 (177.1 mg) was subjected to silica gel (column: $\left.2 \times 28 \mathrm{~cm} ; \mathrm{CH}_{2} \mathrm{Cl}_{2} / \mathrm{MeOH}, 15: 1\right)$ chromatography to give IBM3.3.2.5.2 $(48.6 \mathrm{mg})$. The subfration IBM3.3.2.5.2 was purified by silica gel chromatography (column: $2 \times 28 \mathrm{~cm}$; $n$-hexane/EtOAc, 5:1 and $n$-hexane/acetone, 2:1) to give $20(18.3 \mathrm{mg})$. Subfraction IBM3.3.4 was subjected to silica gel chromatography (column: $2 \times 28 \mathrm{~cm}$; EtOAc/MeOH, 100:1 and $\left.\mathrm{CH}_{2} \mathrm{Cl}_{2} / \mathrm{MeOH}, 20: 1\right)$ and purified by RP-HPLC $\left(\mathrm{MeOH} / \mathrm{H}_{2} \mathrm{O}, 85: 15\right)$ to give compounds 14 (4.9 mg, $\left.\mathrm{t}_{\mathrm{R}}=11 \mathrm{~min}\right)$ and $15\left(2.4 \mathrm{mg}, \mathrm{t}_{\mathrm{R}}=13 \mathrm{~min}\right)$. Fraction IBM5 (3.6 g) was fractionated into six subfractions by Sephadex LH-20 (column: $5 \times 47 \mathrm{~cm}$; MeOH). Subfraction IBM5.3 $(476.7 \mathrm{mg})$ was subjected to silica gel chromatography (column: $2.5 \times 28 \mathrm{~cm} ; \mathrm{CH}_{2} \mathrm{Cl}_{2} / \mathrm{MeOH}, 4: 1$ and column: $2.5 \times 20 \mathrm{~cm} ; \mathrm{CH}_{2} \mathrm{Cl}_{2} / \mathrm{MeOH}$, 3:1) to give 19 (9.0 mg).

The IBB extract $(53.0 \mathrm{~g})$ was chromatographed over Diaion ${ }^{\circledR} \mathrm{HP}-20$ (column: $7.5 \times 42 \mathrm{~cm}$; $\mathrm{H}_{2} \mathrm{O} / \mathrm{MeOH}$ /acetone, 100:0:0; 50:50:0; 0:100:0; 0:0:100) to give four fractions (IBB1-IBB4). Fraction IBB2 $(14.3 \mathrm{~g})$ was subjected to Sephadex LH-20 (column: $5 \times 56 \mathrm{~cm}$; MeOH) to obtain eight subfractions. Subfraction IBB2.3 ( $2.9 \mathrm{~g}$ ) was separated by RP-18 chromatography (column: $2.5 \times 28 \mathrm{~cm} ; \mathrm{MeOH} / \mathrm{H}_{2} \mathrm{O}$, 1:2) to give six subfractions (IBB2.3.1-IBB2.3.6), and subfraction IBB2.3.4 (620.5 mg) was further subjected to RP-18 chromatography (column: $2.5 \times 28 \mathrm{~cm}$; MeOH/ $\mathrm{H}_{2} \mathrm{O}, 1: 1.5$ ) to give three subfractions (IBB2.3.4.1-IBB2.3.4.3). Subfraction IBB2.3.4.2 $(531.9 \mathrm{mg})$ was separated into three subfractions (IBB2.3.4.2.1-IBB2.3.4.2.3) and IBB2.3.4.2.1 (45.5 mg) was purified by silica gel chromatography (column: $\left.2 \times 28 \mathrm{~cm} ; \mathrm{CHCl}_{3} / \mathrm{MeOH}, 6: 1\right)$ to give $7(5.6 \mathrm{mg})$. Subfraction IBB2.3.4.2.2 (305.9 mg) was subjected to RP-18 chromatography (column: $2 \times 28 \mathrm{~cm}$; $\mathrm{MeOH} / \mathrm{H}_{2} \mathrm{O}, 1: 1.5$ and 1:2) and silica gel chromatography (column: $2 \times 28 \mathrm{~cm}$; EtOAc/MeOH, 50:1) to give $6(12.7 \mathrm{mg}$ ). Subfraction IBB2.3.5 (997.0 mg) was separated by silica gel chromatography (column: $2 \times 28 \mathrm{~cm} ; \mathrm{CHCl}_{3} / \mathrm{MeOH}, 8: 1, \mathrm{EtOAc} / \mathrm{MeOH}, 20: 1$ ) and RP-18 chromatography (column: $\left.2 \times 28 \mathrm{~cm} ; \mathrm{MeOH} / \mathrm{H}_{2} \mathrm{O}, 1: 2.5\right)$ to obtain 5 (18.4 mg). Subfraction IBB2.4 (2.0 g) was partitioned by RP-18 chromatography (column: $2 \times 28 \mathrm{~cm}$; $\mathrm{MeOH} / \mathrm{H}_{2} \mathrm{O}, 1: 2$ ) and its subfraction IBB2.4.2 (436.5 mg) was isolated by RP-18 chromatography (column: $2 \times 28 \mathrm{~cm}$; $\mathrm{MeOH} / \mathrm{H}_{2} \mathrm{O}, 1: 2.5$ and 1:2) and then purified by preparative TLC $\left(\mathrm{CH}_{2} \mathrm{Cl}_{2} / \mathrm{MeOH}, 8: 1\right)$ to give 10 $(4.4 \mathrm{mg})$. Subfraction IBB2.5 (3.3 g) was separated into six subfractions by column chromatography with 
RP-18 gel (column: $\left.2 \times 28 \mathrm{~cm} ; \mathrm{MeOH} / \mathrm{H}_{2} \mathrm{O}, 1: 1.5\right)$, and subfraction IBB2.5.2 $(2.1 \mathrm{~g})$ was subjected to RP-18 chromatography (column: $\left.2 \times 28 \mathrm{~cm} ; \mathrm{MeOH} / \mathrm{H}_{2} \mathrm{O}, 1: 1\right)$ to give $\mathbf{1}(613.7 \mathrm{mg})$. Subfraction IBB2.5.3 (972.6 mg) was purified on silica gel (column: $2 \times 28 \mathrm{~cm}$; EtOAc/MeOH, 3:1) and then was subjected to RP-18 chromatography (column: $\left.2 \times 28 \mathrm{~cm} ; \mathrm{MeOH} / \mathrm{H}_{2} \mathrm{O}, 1: 1,1: 1.5\right)$ to give 2 (20.6 mg). Subfraction IBB2.6 (652.2 mg) was subjected to RP-18 chromatography (column: $2 \times 28 \mathrm{~cm}$; $\mathrm{MeOH} / \mathrm{H}_{2} \mathrm{O}, 1: 1,1: 2$ ) to give $4(39.9 \mathrm{mg})$. Fraction IBB3 (3.9 g) yielded nine subfractions (IBB3.1-IBB3.9) after Sephadex LH-20 (column: $5 \times 48 \mathrm{~cm}, \mathrm{MeOH}$ ) chromatography. The subfraction IBB3.3 $(170.0 \mathrm{mg}$ ) was subjected to open column chromatography on silica gel (column: $2 \times 25 \mathrm{~cm}, \mathrm{CHCl}_{3} / \mathrm{MeOH}, 7: 1$ ) and further purified by RP-HPLC (MeCN/ $\left.\mathrm{H}_{2} \mathrm{O}, 20: 80\right)$ to give 8 ( $\left.8.0 \mathrm{mg}, \mathrm{t}_{\mathrm{R}}=16 \mathrm{~min}\right)$. Subfraction IBB3.4 $(220.0 \mathrm{mg})$ was separated by silica gel chromatography (column: $\left.2 \times 25 \mathrm{~cm} ; \mathrm{CHCl}_{3} / \mathrm{MeOH}, 7: 1\right)$ and RP-18 chromatography (column: $1.5 \times 21.5 \mathrm{~cm}$; $\left.\mathrm{MeOH} / \mathrm{H}_{2} \mathrm{O}, 40: 60\right)$ to obtain $9(7.0 \mathrm{mg})$. Subfraction IBB3.9 (52.0 mg) was purified by RP-HPLC ( $\left.\mathrm{MeOH} / \mathrm{H}_{2} \mathrm{O}, 50: 50\right)$ to give $3\left(2.0 \mathrm{mg}, \mathrm{t}_{\mathrm{R}}=32 \mathrm{~min}\right)$.

\subsection{GC/MS Analysis of the n-Hexane-soluble Fraction (IBH)}

(1) HS-SPME analysis: A 50/30- $\mu \mathrm{m}$ divinylbenzene/carboxen/polydimethylsiloxane fiber (Supelco, Inc.) was used for aroma extraction. IBH samples was put into a $7 \mathrm{~mL}$ vial (Hole Cap PTFE/Silicone Septa) and sealed. The SPME fiber was exposed to each sample for $30 \mathrm{~min}$ at $25^{\circ} \mathrm{C}$, after which each sample was injected into a gas chromatograph injection unit [48].

(2) Analysis of the components of samples by GC and GC/MS: Qualitative and quantitative analyses of the volatile compounds were conducted using a 7890A GC (Agilent, Wilmington, DE, USA) equipped with a $60 \mathrm{~m} \times 0.25 \mathrm{~mm}$ i.d. DB-1 fused-silica capillary column with a film thickness of $0.25 \mu \mathrm{m}$ and a flame ionization detector. The injector and detector temperatures were maintained at $250{ }^{\circ} \mathrm{C}$ and $300{ }^{\circ} \mathrm{C}$, respectively. The oven temperature was held at $40^{\circ} \mathrm{C}$ for $1 \mathrm{~min}$ and then raised to $150^{\circ} \mathrm{C}$ at $5{ }^{\circ} \mathrm{C} / \mathrm{min}$ and held for $1 \mathrm{~min}$, finally raised to $200^{\circ} \mathrm{C}$ at $10^{\circ} \mathrm{C} / \mathrm{min}$ and held for $11 \mathrm{~min}$. The carrier gas (nitrogen) flow rate was $1 \mathrm{~mL} / \mathrm{min}$. Kovats indices were calculated for the separated components relative to a $C_{5}-C_{25} n$-alkane mixture [49]. Percentage composition was calculated using the peak area normalization measurements.

(3) Analysis of the components of the samples by GC-MS: The volatile compounds were identified using an Agilent 7890B GC equipped with a $60 \mathrm{~m} \times 0.25 \mathrm{~mm}$ i.d. DB-1 fused-silica capillary column with a film thickness of $0.25 \mu \mathrm{m}$ coupled to an Agilent model 5977 A MSD mass spectrometer (MS). The injector temperature was maintained at $250{ }^{\circ} \mathrm{C}$. The GC conditions in the GC-MS analysis were the same as in the GC analysis. The carrier gas (helium) flow rate was $1 \mathrm{~mL} / \mathrm{min}$. The electron energy was $70 \mathrm{eV}$ at $230^{\circ} \mathrm{C}$. The constituents were identified by matching their spectra with those recorded in a MS library (Wiley 7n) [48].

\subsection{LC/MS Analysis of $\mathrm{H}_{2} \mathrm{O}$-Soluble Fraction (IBW)}

A UHPLC system (Ultimate 3000; Dionex, Germering, Germany) equipped with a C18 reversed-phase column $(2.1 \times 150 \mathrm{~mm}, 3 \mu \mathrm{m}$, T3; Waters, Milford, MA, USA) was coupled with a hybrid Q-TOF mass spectrometer (maXis impact, Bruker Daltonics, Bremen, Germany) with an orthogonal electrospray ionization (ESI) source. The initial flow rate was $0.25 \mathrm{~mL} / \mathrm{min}$ of $99 \%$ solvent A ( $0.1 \%$ formic acid) and $1 \%$ solvent B (MeCN with $0.1 \%$ formic acid). A volume of $2 \mu \mathrm{L}$ of sample was injected. After injection, solvent B was maintained at $1 \%$ for $4 \mathrm{~min}$, then increased to $45 \%$ during a span of $14 \mathrm{~min}$, and finally to $99 \%$ over a period of $2 \mathrm{~min}$ after which this percentage composition was held for $2 \mathrm{~min}$. After $0.5 \mathrm{~min}$, solvent B was reduced back to $1 \%$ and held at this percentage for $2.5 \mathrm{~min}$.

The mass spectrometer was operated in either positive or negative ion mode using the $m / z$ range $50-1000$ at $1 \mathrm{~Hz}$ (summation value of 9839). The capillary voltage of the ion source and negative was set at $+4500 \mathrm{~V}$ for positive mode and $-2500 \mathrm{~V}$ for negative mode, and the endplate offset was $500 \mathrm{~V}$. The nebulizer gas flow was 1 bar and drying gas flow was $8 \mathrm{~L} / \mathrm{min}$. The drying temperature was set at $200{ }^{\circ} \mathrm{C}$. Funnel 1 radiofrequency (RF) and Funnel 2 RF were both $200 \mathrm{Vpp}$. The hexapole RF was $30 \mathrm{Vpp}$ and the low mass cutoff of quadrupole was $100 \mathrm{~m} / \mathrm{z}$. For the MS/MS settings, the eight most 
intense ions from each MS full scan spectrum were automatically selected as the precursor ion peaks for the following auto MS/MS experiments.

\subsection{Acid Hydrolysis and Reversed-Phase HPLC Analysis of IBW}

The IBW crude fraction $(10.0 \mathrm{mg})$ was hydrolyzed in $1 \mathrm{M} \mathrm{HCl} / 1,4$-dioxane $(1: 1,2.0 \mathrm{~mL})$ at $90^{\circ} \mathrm{C}$ for $3 \mathrm{~h}$ and then partitioned with $\mathrm{CH}_{2} \mathrm{Cl}_{2} / \mathrm{H}_{2} \mathrm{O}$ (1:1). The aqueous layer was neutralized with Amberlite IRA400. After drying, the residue was dissolved in pyridine $(1.0 \mathrm{~mL})$ containing L-cysteine methyl ester hydrochloride $(10.0 \mathrm{mg})$ and heated at $60^{\circ} \mathrm{C}$ for $1 \mathrm{~h}$. A $10 \mu \mathrm{L}$ solution of $o$-tosyl isothiocyanate in pyridine was added to the mixture, which was heated at $60^{\circ} \mathrm{C}$ for $1 \mathrm{~h}$. The final reaction mixture was directly analyzed by HPLC: Analytical HPLC was performed on a $250 \times 4.6 \mathrm{~mm}$ i.d. Cosmosil 5C18-AR II column at $35{ }^{\circ} \mathrm{C}$ with isocratic elution of $25 \% \mathrm{CH}_{3} \mathrm{CN}$ in $50 \mathrm{mM} \mathrm{H}_{3} \mathrm{PO}_{4}$ for $40 \mathrm{~min}$ at a flow rate $0.8 \mathrm{~mL} / \mathrm{min}[50]$.

\subsection{Cell Culture}

The 3T3-L1 preadipocytes were cultured as previously described [51]. The cells were grown in Dulbecco's modified Eagle's medium (DMEM) with high glucose containing 10\% $(v / v)$ FBS, $100 \mathrm{U} / \mathrm{mL}$ penicillin and $100 \mu \mathrm{g} / \mathrm{mL}$ streptomycin in plates $\left(10^{5} \mathrm{cells} / \mathrm{mL}\right)$ at $37^{\circ} \mathrm{C}$ in a humidified atmosphere of $10 \% \mathrm{CO}_{2}$. The medium was changed every two days. Primary rat hepatocytes (HCs) were isolated and cultured as previously described [52]. Primary HCs were suspended in William's Medium E containing $10 \%(v / v)$ FBS, $100 \mathrm{U} / \mathrm{mL}$ penicillin, $100 \mu \mathrm{g} / \mathrm{mL}$ streptomycin, $2 \mathrm{mM}$ L-glutamine, $0.86 \mu \mathrm{M}$ insulin, $0.5 \mathrm{nM}$ dexamethasone, and $10 \mathrm{mM}$ HEPES and were plated on collagen-coated dishes $\left(5 \times 10^{5}\right.$ cells $\left./ \mathrm{mL}\right)$. Cells were cultured at $37^{\circ} \mathrm{C}$ with $5 \% \mathrm{CO}_{2}$ for $3 \mathrm{~h}$ for attachment and were washed twice with PBS. The medium was then changed, and, the cells were used for experiments after overnight incubation.

\subsection{Cell Viability and Proliferation}

The cells were treated with different concentrations of crude fractions or pure compounds for the indicated time points. Cell viability was assayed using the Trypan blue exclusion method. The cells were stained with Trypan blue. The unstained (viable) and stained (dead) cells were counted separately using a hemocytometer under a microscope (Nikon TS100). The cell viability was calculated based on the ratio of viable cells to total cell population in each plate. Cell proliferation was assayed using MTT metabolic analysis. MTT was added to the cell medium, and after incubation at $37^{\circ} \mathrm{C}$ for $4 \mathrm{~h}$, the blue formazan reduction product was dissolved in isopropanol and measured on an ELISA reader at $570 \mathrm{~nm}[51]$.

\subsection{Differentiation of 3T3-L1 Cells into Mature Adipocytes}

3T3-L1 cells were cultured from preadipocytes and differentiated into adipocytes as previously described. Preadipocytes were grown in Dulbecco's modified Eagle's medium (DMEM) with high glucose containing $10 \%(v / v)$ FBS, $100 \mathrm{U} / \mathrm{mL}$ penicillin, and $100 \mu \mathrm{g} / \mathrm{mL}$ streptomycin in plates $\left(10^{5}\right.$ cells $\left./ \mathrm{mL}\right)$ at $37^{\circ} \mathrm{C}$ in a humidified atmosphere of $10 \% \mathrm{CO}_{2}$. The medium was changed every 2 days. Then, two days after confluence, the medium was replaced with DMEM (high glucose) containing 10\% FBS and adipogenic agents (1.7 $\mu \mathrm{M}$ insulin, $0.25 \mu \mathrm{M} \mathrm{DMX}$, and $0.5 \mathrm{mM}$ IBMX); this day was designated day 0 and occurred after three days of culturing. The cells were then grown in DMEM containing $10 \%$ FBS, and the medium was changed every two days. Differentiated cells were used for experimentation on day 9 when the proportion of differentiated cells reached up to $90 \%$. The differentiated cells were identified by Oil Red O staining and by gradient centrifugation with Percoll [53]. 


\subsection{Western Blot Analysis}

The cells were treated as indicated, detached, thoroughly washed with PBS, and then lysed in ice-cold lysis buffer. Following centrifugation at $13,000 \times \mathrm{g}$ for $10 \mathrm{~min}$ at $4{ }^{\circ} \mathrm{C}$, the supernatants (30 $\mu \mathrm{g}$ protein) were boiled with reducing sample buffer for $5 \mathrm{~min}$, subjected to electrophoresis in SDS-polyacrylamide gels, and then transferred onto a PVDF membrane. The membrane was blocked with 1\% BSA in PBS containing 0.1\% Tween-20 (PBST) for $1 \mathrm{~h}$ at room temperature and then washed with PBST. Proteins were detected by incubating the membrane overnight at $4{ }^{\circ} \mathrm{C}$ with antibodies against $\beta$-actin (Sigma-Aldrich), Glut4 (IF8), p-Glut4 (Ser 488) (Santa Cruz Biotechnology, Santa Cruz, CA, USA), Akt (pan), p-Akt (Ser 473), p-PI3K (Tyr458/Tyr199) (Cell Signaling Technology, Danvers, MA, USA). Next, the membrane was washed with PBST, and, finally, the membrane was incubated with a secondary antibody conjugated to horseradish peroxidase (HRP) for $1 \mathrm{~h}$. An enhanced chemiluminescence (ECL) kit (Amersham Biosciences, Arlington Heights, IL, USA or Millipore, Billerica, MA, USA) was used for protein detection.

\subsection{Glucose Uptake Assay}

The differentiated 3T3-L1 adipocytes or primary rat hepatocytes were cultured with low glucose DMEM for $6 \mathrm{~h}$, and then PBS including $1 \%$ bovine serum albumin (BSA) was added. The crude extracts $(0.1 \mathrm{mg} / \mathrm{mL})$ and pure compounds $(0.01 \mathrm{mg} / \mathrm{mL})$ were added to the medium for the indicated time and then stimulated with $10^{-7} \mathrm{M}$ insulin at $37^{\circ} \mathrm{C}$ for another $30 \mathrm{~min}$. A $10^{-4} \mathrm{M}$ fluorescent D-glucose analog (2-[N-(7-nitrobenz-2-oxa-1,3-diazol-4-yl)amino]-2-deoxyglucose, 2-NBDG) was added to the former 3T3-L1 adipocytes for $30 \mathrm{~min}$ and then PBS was used to wash the cells three times. Some cell lysis buffers were used to obtain the cell extracts, which were homogenized with an ultrasonicator to assay the fluorescence with excitation and emission at 485 and $535 \mathrm{~nm}$, respectively.

\section{Conclusions}

In conclusion, four crude fractions (IBH, IBM, IBB, and IBM) were prepared from purple I. batatas leaves and 21 compounds were isolated. The IBH crude extract, with methyl decanoate (22) as a major and active component, showed antihyperglycemic potential in vitro. In a glucose uptake assay, flavonoids $\mathbf{1}$ and $\mathbf{3}$, as well as benzene derivatives $\mathbf{1 0}$ and $\mathbf{1 2}$, were identified as promising lead compounds, especially quercetin (3). Overall, our data systematically demonstrated that purple sweet potato leaves are a potential antidiabetic plant source. We believe that further investigation is definitely merited.

Supplementary Materials: Supplementary materials can be accessed at: http:/ /www.mdpi.com/1420-3049/21/ 6/745/s1.

Acknowledgments: We are grateful to the Chinese Medicine Research Center, China Medical University (Ministry of Education, Aim for the Top University Plan) for the lab space support. The authors deeply appreciate Susan L. Morris-Natschke for English revision (Natural Products Research Laboratories, UNC, USA). This work was supported by the grant from Ministry of Science and Technology, Taiwan (NSC 101-2632-B-039-001-MY3) awarded to YCW.

Author Contributions: Conceived and designed the experiments: C.-L.L., S.-L.L., C.-J.C., M.-C.K. and Y.C.W. Performed the experiments: C.-L.L., H.-C.C., C.-H.L., J.-Y.C. and Y.-T.L. Analyzed the data: C.-L.L., S.-L.L., C.-J.C. and H.-C.C. Contributed reagents/materials/analysis tools: C.-L.L., S.-L.L., C.-J.C., H.-C.C., M.-C.K. and Y.-C.W. Wrote the paper: C.-L.L., S.-L.L., C.-J.C. and H.-C.C.

Conflicts of Interest: The authors declare no conflict of interest.

\section{Abbreviations}

The following abbreviations are used in this manuscript:

TLC Thin-Layer Chromatography

RP-18 Reversed-Phase Carbon-18

EtOAc Ethyl Acetate 


$\begin{array}{ll}n-\mathrm{BuOH} & \text { Normal Butanol } \\ \mathrm{MeOH} & \text { Methanol } \\ \mathrm{HPLC} & \text { High-Performance Liquid Chromatography } \\ \text { NMR } & \text { Nuclear Magnetic Resonance } \\ \text { HSQC } & \text { Heteronuclear Single Quantum Coherence } \\ \mathrm{HMBC} & \text { Heteronuclear Multiple Bond Correlation } \\ \mathrm{COSY} & \text { Correlation Spectroscopy } \\ \text { NOESY } & \text { Nneclear Overhauser Exchange Spectroscopy } \\ \text { ESIMS } & \text { Electrospray Ionisation Mass Spectrometry } \\ \text { GC/MS } & \text { Gas Chromatography-Mass } \\ \text { LC/MS } & \text { Liquid Chromatography-Mass } \\ t_{\mathrm{R}} & \text { Retention Time }\end{array}$

\section{References}

1. Mohanraj, R.; Sivasankar, S. Sweet potato (Ipomoea batatas [L.] Lam)—A valuable medicinal food: A review. J. Med. Food. 2014, 17, 733-741. [CrossRef] [PubMed]

2. Li, F.; Li, Q.; Gao, D.; Peng, Y. The optimal extraction parameters and anti-diabetic activity of flavonoids from Ipomoea batatas leaf. Afr. J. Trad. CAM 2009, 6, 195-202. [CrossRef]

3. Oki, N.; Nonaka, S.; Ozaki, S. The effects of an arabinogalactan-protein from the white-skinned sweet potato (Ipomoea batatas L.) on blood glucose in spontaneous diabetic mice. Biosci. Biotechnol. Biochem. 2011, 75, 596-598. [CrossRef] [PubMed]

4. Zhao, J.G.; Yan, Q.Q.; Xue, R.Y.; Zhang, J.; Zhang, Y.Q. Isolation and identification of colourless caffeoyl compounds in purple sweet potato by HPLC-DAD-ESI/MS and their antioxidant activities. Food Chem. 2014, 161, 22-26. [CrossRef] [PubMed]

5. Dini, I.; Tenore, G.C.; Dini, A. New polyphenol derivative in Ipomoea batatas tubers and its antioxidant activity. J. Agric. Food Chem. 2006, 54, 8733-8737. [CrossRef] [PubMed]

6. Yoshikawa, K.; Yagi, C.; Hama, H.; Tanaka, M.; Arihara, S.; Hashimoto, T. Ipomotaosides A-D, resin glycosides from the aerial parts of Ipomoea batatas and their inhibitory activity against COX-1 and COX-2. J. Nat. Prod. 2010, 73, 1763-1766. [CrossRef] [PubMed]

7. Ludvik, B.; Waldhäusl, R.P.; Kautzky-Willer, A.; Pacini, G. Mode of action of Ipomoea batatas (Caiapo) in type 2 diabetic patients. Metabolism 2003, 52, 875-880. [CrossRef]

8. Ludvik, B.; Neuffer, B.; Pacini, G. Efficacy of Ipomoea batatas (Caiapo) on diabetes control in type 2 diabetic subjects treated with diet. Diabetes Care 2004, 27, 436-440. [CrossRef] [PubMed]

9. Ludvik, B.; Hanefeld, M.; Pacini, G. Improved metabolic control by Ipomoea batatas (Caiapo) is associated with increased adiponectin and decreased fibrinogen levels in type 2 diabetic subjects. Diabetes Obes. Metab. 2008, 10, 586-592. [CrossRef] [PubMed]

10. Wang, M.; Xiong, Y.; Zeng, M.; Li, H.; Zhang, T.; Liang, Y. GC-MS combined with chemometrics for analysis of the components of the essential oils of sweet potato leaves. Chromatographia 2010, 71, 891-897. [CrossRef]

11. Cui, E.J.; Song, N.Y.; Shrestha, S.; Chung, I.S.; Kim, J.Y.; Jeong, T.S.; Baek, N.I. Flavonoid glycosides from cowpea seeds (Vigna sinensis K.) inhibit LDL oxidation. Food Sci. Biotechnol. 2012, 21, 619-624. [CrossRef]

12. Fossen, T.; Pedersen, A.T.; Andersen, Ø.M. Flavonoids from red onion (Allium cepa). Phytochemistry 1998, 47, 281-285. [CrossRef]

13. Ono, M.; Masuoka, C.; Odake, Y.; Ikegashira, S.; Ito, Y.; Nohara, T. Antioxidative constituents from Tessaria integrifolia. Food Sci. Technol. Res. 2000, 6, 106-114. [CrossRef]

14. Xu, X.; Xie, H.; Hao, J.; Jiang, Y.; Wei, X. Eudesmane sesquiterpene glucosides from lychee seed and their cytotoxic activity. Food Chem. 2010, 123, 1123-1126. [CrossRef]

15. Liu, H.Y.; He, H.P.; Gao, S.; Chen, C.X.; Shen, Y.M.; Hao, X.J. Two new diterpenoids from Callicarpa pedunculata. Helv. Chim. Acta. 2006, 89, 1017-1022. [CrossRef]

16. Morvai, M.; Nagy, T.; Kocsis, Á.; Szabó, L.F.; Podányi, B. Effect of oxygen substituents on two- and three-bond carbon-proton spin-spin coupling constants. Magn. Reson. Chem. 2000, 38, 343-359. [CrossRef]

17. Ishikawa, T.; Kondo, K.; Kitajima, J. Water-soluble constituents of coriander. Chem. Pharm. Bull. 2003, 51, 32-39. [CrossRef] [PubMed] 
18. Williams, P.J.; Strauss, C.R.; Wilson, B. New linalool derivatives in muscat of Alexandria grapes and wines. Phytochemistry 1980, 19, 1137-1139. [CrossRef]

19. Takeda, Y.; Ooiso, Y.; Masuda, T.; Honda, G.; Otsuka, H.; Sezik, E.; Yesilada, E. Iridoid and eugenol glycosides from Nepeta cadmea. Phytochemistry 1998, 49, 787-791. [CrossRef]

20. Elgendy, E.M.; Khayyat, S.A. Oxidation reactions of some natural volatile aromatic compounds: Anethole and eugenol. Russ. J. Org. Chem. 2008, 44, 823-829. [CrossRef]

21. Kim, M.R.; Moon, H.T.; Lee, D.G.; Woo, E.R. A new lignan glycoside from the stem bark of Styrax japonica S. et Z. Arch. Pharm. Res. 2007, 30, 425-430. [CrossRef] [PubMed]

22. Seigler, D.S.; Pauli, G.F.; Nahrstedt, A.; Leen, R. Cyanogenic allosides and glucosides from Passiflora edulis and Carica papaya. Phytochemistry 2002, 60, 873-882. [CrossRef]

23. Ito, J.; Chang, F.R.; Wang, H.K.; Park, Y.K.; Ikegaki, M.; Kilgore, N.; Lee, K.H. Anti-AIDS agents. 48. Anti-HIV activity of moronic acid derivatives and the new melliferone-related triterpenoid isolated from Brazilian propolis. J. Nat. Prod. 2001, 64, 1278-1281. [CrossRef] [PubMed]

24. Yin, X.J.; Xu, G.H.; Sun, X.; Peng, Y.; Ji, X.; Jiang, K.; Li, F. Synthesis of bosutinib from 3-methoxy-4-hydroxybenzoic acid. Molecules 2010, 15, 4261-4266. [CrossRef] [PubMed]

25. Nakajima, E.; Nakano, H.; Yamada, K.; Shigemori, H. Isolation and identification of lateral bud growth inhibitor, indole-3-aldehyde, involved in apical dominance of pea seedlings. Phytochemistry 2002, 61, 863-865. [CrossRef]

26. Jerezano, A.; Jiménez, F.; Cruz, M.C.; Montiel, L.E.; Delgado, F.; Tamariz, J. New approach for the construction of the coumarin frame and application in the total synthesis of natural products. Helv. Chim. Acta 2011, 94, 185-198. [CrossRef]

27. Yamazaki, Y.; Kawano, Y.; Uebaysai, M. Induction of adiponectin by natural and synthetic phenolamides in mouse and human preadipocytes and its enhancement by docosahexaenoic acid. Life Sci. 2008, 82, 290-300. [CrossRef] [PubMed]

28. Ghosh, S.K.; Butler, M.S.; Lear, M.J. Synthesis of 2-C-methylerythritols and 2-C-methylthreitols via enantiodivergent sharpless dihydroxylation of trisubstituted olefins. Tetrahedron Lett. 2012, 53, 2706-2708. [CrossRef]

29. Matsuda, T.; Kuroyanagi, M.; Sugiyama, S.; Umehara, K.; Ueno, A.; Nishi, K. Cell differentiation-inducing diterpenes from Andrographis paniculata. Chem. Pharm. Bull. 1994, 42, 1216-1225. [CrossRef] [PubMed]

30. Faizi, S.; Ali, M.; Saleem, R.; Irfanullah; Bibi, S. Complete ${ }^{1} \mathrm{H}-$ and ${ }^{13} \mathrm{C}-\mathrm{NMR}$ assignments of stigma-5-en-3-O- $\beta$-glucoside and its acetyl derivative. Magn. Reson. Chem. 2001, 39, 399-405. [CrossRef]

31. Nozière, B.; González, N.J.D.; Borg-Karlson, A.K.; Pei, Y.; Redeby, J.P.; Krejci, R.; Dommen, J.; Prevot, A.S.H.; Anthonsen, T. Atmospheric chemistry in stereo: A new look at secondary organic aerosols from isoprene. Geophys. Res. Lett. 2011, 38, L11807/1-L11807/5. [CrossRef]

32. Basu, A.; Basu, R.; Shah, P.; Vella, A.; Johnson, C.M.; Nair, K.S.; Jensen, M.D.; Schwenk, W.F.; Rizza, R.A. Effects of type 2 diabetes on the ability of insulin and glucose to regulate splanchnic and muscle glucose metabolism: Evidence for a defect in hepatic glucokinase activity. Diabetes 2000, 49, 272-283. [CrossRef] [PubMed]

33. Iozzo, P.; Hallsten, K.; Oikonen, V.; Virtanen, K.A.; Kemppainen, J.; Solin, O.; Ferrannini, E.; Knuuti, J.; Nuutila, P. Insulin-mediated hepatic glucose uptake is impaired in type 2 diabetes: Evidence for a relationship with glycemic control. J. Clin. Endocrinol. Metab. 2003, 88, 2055-2060. [CrossRef] [PubMed]

34. Arha, D.; Pandeti, S.; Mishra, A.; Srivastava, S.P.; Srivastava, A.K.; Narender, T.; Tamrakar, A.K. Deoxyandrographolide promotes glucose uptake through glucose transporter-4 translocation to plasma membrane in L6 myotubes and exerts antihyperglycemic effect in vivo. Eur. J. Pharmacol. 2015, 768, 207-216. [CrossRef] [PubMed]

35. Gao, Y.; Zhang, M.; Wu, T.; Xu, M.; Cai, H.; Zhang, Z. Effects of D-pinitol on insulin resistance through the PI3K/Akt signaling pathway in type 2 diabetes mellitus rats. J. Agric. Food Chem. 2015, 63, 6019-6026.

36. Lee, H.; Li, H.; Noh, M.; Ryu, J.H. Bavachin from Psoralea corylifolia improves insulin-dependent glucose uptake through insulin signaling and AMPK activation in 3T3-L1 adipocytes. Int. J. Mol. Sci. 2016, 17, 527. [CrossRef] [PubMed]

37. Lee, W.; Yoon, G.; Kim, M.C.; Kwon, H.C.; Bae, G.U.; Kim, Y.K.; Kim, S.N. 5,7-Dihydoxy-6-geranylflavanone improves insulin sensitivity through PPAR $\alpha / \gamma$ dual activation. Int. J. Mol. Sci. 2016, 37, 1397-1404. 
38. Krishna, M.S.; Joy, B.; Sundaresan, A. Effect on oxidative stress, glucose uptake level and lipid droplet content by apigenin 7,4'-dimethyl ether isolated from Piper longum L. J. Food Sci. Technol. 2015, 52, 3561-3570. [PubMed]

39. Matsukawa, T.; Inaquma, T.; Han, J.; Villareal, M.O.; Isoda, H. Cyanidin-3-glucoside derived from black soybeans ameliorate type 2 diabetes through the induction of differentiation of preadipocytes into smaller and insulin-sensitive adipocytes. J. Nutr. Biochem. 2015, 26, 860-867. [CrossRef] [PubMed]

40. Nquyen, P.H.; Ji, D.J.; Han, Y.R.; Choi, J.S.; Rhyu, D.Y.; Min, B.S.; Woo, M.H. Selaginellin and biflavonoids as protein tyrosine phosphatase $1 \mathrm{~B}$ inhibitors from Selaginella tamariscina and their glucose uptake stimulatory effects. Bioorg. Med. Chem. 2015, 23, 3730-3737.

41. Thakkar, C.S.; Kate, A.S.; Desai, D.C.; Ghosh, A.R.; Kulkarni-Almeida, A.A. NFAT-133 increase glucose uptake in L6 myotubes by activating AMPK pathway. Eur. J. Pharmacol. 2015, 769, 117-126. [CrossRef] [PubMed]

42. Kato, E.; Inaqaki, Y.; Kawabata, J. Higenamine 4 '-O- $\beta$-D-glucoside in the lotus plumule induces glucose uptake of L6 cells through $\beta 2$-adrenergic receptor. Bioorg. Med. Chem. 2015, 23, 3317-3321. [CrossRef] [PubMed]

43. Shyni, G.L.; Kavitha, S.; Indu, S.; Arya, A.D.; Anusree, S.S.; Vineetha, V.P.; Vandana, S.; Sundaresan, A.; Raghu, K.G. Chebulagic acid from Terminalia chebula enhances insulin mediated glucose uptake in 3T3-L1 adipocytes via PPAR $\gamma$ signaling pathway. Biofactors. 2014, 40, 646-657. [CrossRef] [PubMed]

44. Kotowska, D.; EI-Houri, R.B.; Borkowski, K.; Petersen, R.K.; Frette, X.C.; Wolber, G.; Grevsen, K.; Christensen, K.B.; Christensen, L.P.; Kristiansen, K. Isomeric C12-alkamides from the roots of Echinacea purpurea improve basal and insulin-dependent glucose uptake in 3T3-L1 adipocytes. Planta Med. 2014, 80, 1712-1720. [CrossRef] [PubMed]

45. Cai, J.; Zhao, L.; Zhu, E.; Guo, J. Stimulating effect of a new triterpene derived from Anoectochilus elwesii on glucose uptake in insulin-resistant human HepG2 cells. Nat. Prod. Res. 2014, 28, 2163-2168. [CrossRef] [PubMed]

46. Fang, X.K.; Gao, J.; Zhu, D.N. Kaempferol and quercetin isolated from Euonymus alatus improve glucose uptake of 3T3-L1 cells without adipogenesis activity. Life Sci. 2008, 82, 615-622. [CrossRef] [PubMed]

47. Nidhina, P.A.H.; Poulose, N.; Gopalakrishnapillai, A. Vanillin induces adipocyte differentiation in 3T3-L1 cells by activating extracellular signal regulated kinase 42/44. Life Sci. 2011, 88, 675-680. [CrossRef] [PubMed]

48. Yeh, C.H.; Tsai, W.Y.; Chiang, H.M.; Wu, C.S.; Lee, Y.I.; Lin, L.Y.; Chen, H.C. Headspace solid-phase microextraction analysis of volatile components in Phalaenopsis Nobby's Pacific Sunset. Molecules 2014, 19, 14080-14093. [CrossRef] [PubMed]

49. Schomburg, G.; Dielmann, G. Identification by means of retention parameters. J. Chromatogr. Sci. 1973, 11, 151-159. [CrossRef]

50. Tanaka, T.; Nakashima, T.; Ueda, T.; Tomii, K.; Kouno, I. Facile discrimination of aldose enantiomers by reversed-phase HPLC. Chem. Pharm. Bull. 2007, 55, 899-901. [CrossRef]

51. Lee, S.L.; Lee, H.K.; Chin, T.Y.; Tu, S.C.; Kuo, M.H.; Kao, M.C.; Wu, Y.C. Inhibitory effects of purple sweet potato leaf extract on the proliferation and lipogenesis of the 3T3-L1 preadipocytes. Am. J. Chin. Med. 2015, 43, 915-925. [CrossRef] [PubMed]

52. Lee, S.L.; Chin, T.Y.; Lai, C.L.; Wang, W.H. Sedum mexicanum Britt. induces apoptosis of primary rat activated hepatic stellate cells. Evid. -Based Complement. Altern. Med. 2015. [CrossRef]

53. Lee, S.L.; Chin, T.Y.; Tu, S.C.; Wang, Y.J.; Hsu, Y.T.; Kao, M.C.; Wu, Y.C. Purple sweet potato leaf extract induces apoptosis and reduces inflammatory adipokine. Evid. Based Complement. Altern. Med. 2015. [CrossRef]

Sample Availability: Samples of the compounds 1-24 are available from the author Y.-C.W. 